\title{
Iot Framework Current Trends and Recent Advances to Management Company in The PT.TNC
}

\section{Tren Saat ini dan Kemajuan Terbaru Framework IoT untuk Manajemen Perusahaan pada PT.TNC}

\author{
Teddy Surya Gunawan', B . Herawan Hayadi², Cindy Paramitha ${ }^{3}$, Muhammad Sadikin ${ }^{4}$ \\ 1,2,3,4 Universitas Potensi Utama, Fakultas Teknik dan Ilmu Komputer, Medan \\ e-mail: ${ }^{1}$ tsgunawan@gmail.com,${ }^{2}$ b.herawan.hayadi@ gmail.com,${ }^{3}$ cndparamitha@ gmail.com, ${ }^{4}$ \\ diki.potensiutama@gmail.com
}

\begin{abstract}
The Internet of Things (IoT) is a fast growing and user-friendly technology that connects everything together. And it can communicate effectively between the people who connect "Things." Internet of Things, also known as Internet of Objects, usually refers to remote systems between projects. Systems will be remote and self-designable. However, the world's largest information technology companies tend to release products in the form of services to avoid disclosing detailed design and implementation knowledge. Hence, the overall trend of academic institutions is to use these mainstream IoT platforms as "black boxes". IoT is something that is useful as a sensor, computer architecture, software, security, packaging, technology selection based on the amount of data, as far as data is needed, whatever power you have. Fundamental way to collect and store data Thing: $S Q L$, noSQL, and time series databases Machine learning algorithms with outputs: regression, classification, anomaly detection. Improve service quality, reduce service costs New models (precision services), Reduce consumption costs of higher quality products or services, Improve health and safety.
\end{abstract}

Keywords: IoT, Framework, SQL Server, Security

\begin{abstract}
Abstrak
Internet of Things (IoT) adalah teknologi yang berkembang cepat dan ramah pengguna yang menghubungkan semuanya bersama-sama Dan itu dapat berkomunikasi secara efektif antara orang-orang yang terhubung "Things." Internet of Things, juga dikenal sebagai Internet of Objects, biasanya mengacu pada sistem jarak jauh antar proyek. Sistem akan jauh dan dapat dirancang sendiri.Namun, perusahaan teknologi informasi terbesar di dunia cenderung merilis produk dalam bentuk layanan untuk menghindari pengungkapan pengetahuan detail desain dan implementasi. Oleh karena itu, tren keseluruhan institusi akademik adalah menggunakan platform IoT arus utama ini sebagai "kotak hitam". IoT sesuatu yang berguna sebagai Sensor, arsitektur komputer, perangkat lunak, keamanan, pengemasan, pemilihan teknologi berdasarkan jumlah data, sejauh data yang dibutuhkan, apapun daya yang Anda miliki. Cara mendasar untuk mengumpulkan dan menyimpan data Hal: SQL, noSQL, dan database rangkaian waktu Algoritme pembelajaran mesin dengan keluaran: regresi, klasifikasi, anomali deteksi. Meningkatkan kualitas layanan, mengurangi biaya layanan Model baru (layanan presisi), Menurunkan biaya konsumsi Produk atau layanan berkualitas lebih tinggi, Peningkatan kesehatan dan keselamatan.
\end{abstract}

Kata Kunci : IoT, Framework, SQL Server, Security. 


\section{INTRODUCTION}

Today's technological developments change every day. Competition between trading companies, industrial companies, and service companies is happening all the time, and sometimes getting tougher. This kind of competition brings more complex problems for the company.

The technologies used in IoT implantation are: Internet, IPv6, RFID, wireless sensor networks (WSN) and cloud systems. The Internet of Things uses a range of technologies to provide connections between sensor devices. Connectivity is an important issue that will be provided by Internet and wireless technology. Physical objects, actuators and controllers will be linked together via an Internet connection with a unique identifier. Physical objects can also sense events, messages, and forward data to the base station (SINK)[1].

One of the problems that is often faced is the difficulty of companies to organize and manage all the information needed in company activities in a comprehensive and integrated system, thus encouraging the company's internal management processes. Improper management of information systems can hinder every activity of the company, while companies need effective, fast and accurate information as a reference in making strategic decisions.

For this reason, a relative measurement system based on the Internet of Things and artificial intelligence is needed. Internet of Things, also known as IoT acronym, is the concept it aims to extends the benefits of continually connected internet connectivity. The capabilities of IoT technology are to share data, remote control, and control equipment [2].

For data recording activities, the company still uses Microsoft Office Excel 2003, even though it is only used for manual input of reports, and financial reports are still limited to LT (annual reports), so the possibility of bookkeeping errors is very high. The source of company funds comes from the company's operating profit.

Internet of Things (IoT) is a collection of objects objects (things), in the form of physical devices (hardware / embedded systems) capable of exchanging information between information sources, service operators or other devices connected to the system so that they can provide greater benefit [3]. Including to make an electrical control system from the distribution transformer so that it can work optimally and can solve the problem of power outages [4].

On the basis of these problems, the authors feel attracted to make an information system design that can ensure security in helping companies to manage company management by utilizing the Internet of Things (IoT).

Which is where the Internet of Things (IoT) is a fast-growing and user-friendly technology that connects everything together. And it can communicate effectively between people connected to "Things." Internet of Things, also known as Internet of Objects, usually refers to remote systems between projects.

IoT is driving real results today. Two-thirds of respondents are currently working on IoT projects or will be in the next 18 months, AWS, Azure, and GCP are the leading IoT cloud platforms, most IoT developers use C, C ++, Java, JavaScript, and Python, MQTT is still the The dominant communication protocol utilized by developers, Eclipse Desktop IDE is the leading IDE for building IoT applications.

In accordance with the explanation that has been described on the background of the problems above, the authors can identify the problems that are relevant enough to be raised in this study, namely: a) Security management in data storage often experiences problems that cause some data to leak due to the absence of better security; b) The information system used in reporting the data collection on goods has not been computerized, so that it will make it difficult to organize accounting data, especially those related to recording and reporting of consumable goods in the company. 


\section{METHOD}

Broadly speaking, the Internet of Things or the Internet of Things is a communication technology between machines that are connected using the Internet. This form of intelligent communication with human managers and users is also called machine-to-machine (M2M). Just like machines in factories, banking equipment, security cameras in public places, even sensors in the agricultural sector, they can all be smart devices. The Internet of Things is not limited to an industrial environment but can also be used for daily needs. Such as home sound control, doorbells, smart lights, indoor pollution monitors, etc. When your various business assets are connected to the Internet, you can get detailed information about current or real-time business conditions. Therefore, operational planning can be carried out based on correct data, monitoring performance, and maintaining product quality.

Internet of Things: The ability of various devices to connect and exchange data over the Internet. The Internet of Things is a technology that enables control, communication, and collaboration with a variety of hardware and data over the Internet. Therefore, it can be said that the Internet of Things (IoT) is when we connect things that are not operated by humans to the Internet [5], but IoT is not only related to remote device control, but also related to sharing methods. . Data, virtualization of all real things into the form of the Internet, etc. The internet automatically becomes the link between machines. In addition, several users immediately act as supervisors for the operation of the tool. The advantage of using IoT technology is that the work done by humans becomes faster, younger, and more efficient.

In 1989, John Romkey and Simon Hackett connected a toaster to the Internet that could be run under computer commands. At the time, this concept was called the "embedded Internet" or "pervasive computing." However, after the introduction of RFID technology or radio frequency identification technology in 1999, Kevin Ashton coined the term "Internet of Things".

The development of the Internet of Things has started. Starting from the innovation of RFID which allows tracking of goods remotely via radio frequency, to various innovations of data display objects in the form of colored balls or rabbit robots, to the use of the Internet Protocol (IP) on smart object networks in 2008, and IPv6 in 2011, They provide information about the identity and location of the device on the Internet network.

Internet of Things technology continues to develop today. As shown in the following Hype-Cycle image researched by Gartner in 2019, the Internet of Things market is expected to mature enough so that the technology will be more stable and widely accepted by the market within 5-10 years. After entering the second and third generations, the risk of implementing the Internet of Things will be reduced, and $20 \%$ of the target market will use the Internet of Things. There is no alternative text for this image

Internet of Things is not just a tool, but also a technical solution that will provide a new aspect of business activities, namely visibility. With IoT solutions, business owners can understand their business conditions in real time. For example, the Managed SD-WAN solution demonstrates the use of Internet data in a business branch and provides control over management of headquarters Internet traffic. As another example, an asset performance management (APM) solution can provide visibility into the physical state of an asset (such as temperature, humidity, lighting), regardless of the location of the asset. Visibility simplifies communication lines in companies, facilitates monitoring, improves security, and ensures that all planning is based on specific data in IoT solutions.

The Internet of Things relies on the Internet as a connection between sensors or devices, and these sensors or devices will communicate with each other in the cloud. The data sent from the sensor to the cloud will be processed by the software, which will determine the next steps. These actions can be sending alerts, customizing plans, closing access to tools, or more. The IoT solution can be controlled by the user via a dashboard on a computer, laptop, or other mobile device. Users or employees who have been granted permission can regulate and change operations and rules according to company needs. These changes will be sent back to the cloud, 
and the appropriate sensors will be updated as soon as possible. We will cover each part of this IoT system in the next section.

Technologies such as artificial intelligence, machine learning and computer vision can be added to IoT systems. But in its simplest form, here are the four main elements that make up an IoT system:

a. Sensor or device

Sensors or devices There are many forms of IoT solutions. Sometimes a device has multiple sensors. For example, the INTANK liquid asset management solution has a temperature sensor and a level gauge sensor. Asset monitoring solutions (such as APM) have 2 devices to check, which are placed in the asset and the asset room or transport. According to their respective uses, these sensors are responsible for collecting data at any time according to a specified time interval. Because the data collected by the sensor is very small, the battery in the device can be used longer, for example the NB-IoT sensor can last for 10 years without the need to replace the battery.

b. Connectivity

Without a connection, the data on the device will not be able to reach the system. The communication methods between devices and IoT systems may differ. Cellular, satellite, WiFi, Bluetooth, low power wide area network (LPWAN) connection, etc. Connection options are always tailored to suit user needs. For industries that use a lot of small devices on a large scale, such as the agricultural industry and power distribution, LPWAN is the right connection type. At the same time, the same applies to SD-WAN and managed service connectivity for the financial industry that requires high security.

c. Data processing

When data from the sensor enters the cloud, processing begins. Because the data is always up to date and always updated, the software can see the progress of the asset in real time and ensure that the asset activity meets the predefined rules / parameters. The process is as simple as confirming the delivery truck maintenance date on the Fleet Sight solution. It can also be complicated, for example by using Computer Vision technology to identify the use of masks or personal protective equipment (PPE) in public places through images captured by security cameras. This process is very fast and immediately activates immediate action, such as notifying a fleet manager of truck maintenance needs or notifying security personnel who are not wearing PPE in a designated area.

d. Dashboard or User Interface

The dashboard is where data is displayed so that users can observe real-time activity happening across all devices in the company. Users can also change the settings, rules and operations performed by the IoT system here. For example, by using the location information function (LOCI) as a device location tracker, you can create a rule that the EDC machine cannot leave the store. Then you can define automatic action, if this rule is broken, it will happen. In this case, you can close the SIM card connection at EDC to make sure no data is stolen. This feature is called "set and forget automation" and instructs the system to always use the same action when a similar situation occurs.

IoT hardware is the first thing needed to build an IoT device is a sensor, which will be able to sense the situation in a certain environment, then a remote dashboard is needed to monitor the sensor output and display it on the interface more clearly and clearly. clearer form. It is easier to understand. Lastly, you need a device with service and routing capabilities. The main task of the system is to detect certain conditions and act accordingly. One thing to keep in mind is the communication between the device and the dashboard. In our environment, some of the common sensors are accelerometer, temperature sensor, magnetometer, proximity sensor, gyroscope, image sensor, acoustic sensor, light sensor, pressure sensor, RFID gas sensor, humidity sensor, and microflow sensor.

Currently, we still have many controllable devices, such as smartwatches, shoes and 3D glasses. This is the best example of a smart solution. The 3D glasses adjust the brightness and 
contrast of the TV according to our eyes, while the smartwatch tracks the user's daily activity and fitness.

However, the most important devices that are making a major contribution to the Internet of Things are cellphones / smartphones. Mobile applications have promoted a revolution in technology at a rapid pace. Mobile phones are equipped with applications and sensors that can provide a lot of information about the user. The mobile application has geographic location information, can detect and track lighting conditions, device orientation and more. This app also comes with several connection options, such as Wi-Fi, Bluetooth, and cellular data, which can help one device communicate with another. Therefore, because the standard quality of this mobile phone is at the core of the IoT ecosystem. Today, smartphones can interact with smartwatches and fitness bracelets to simplify and improve the user experience.

The Internet of Things uses many technologies and protocols to communicate with devices as needed. Most of the technologies and protocols are Bluetooth, wireless, NFC, RFID, radio protocol, and Wi-Fi-Direct.

Thus, it can be concluded that the Internet of Things is a connection between a device or device with the internet network, so that these devices can interact and work independently in accordance with the data obtained and processed independently [6].

The application of the Internet of Things continues to grow in the industrial and market sectors. The Internet of Things has had many expansions in various industrial fields. This involves all user groups, from those trying to reduce and convert the energy in their homes to large organizations looking to improve their business operations. The Internet of Things can be used not only to optimize key applications in many organizations, but also to drive the advanced automation concepts we created about a decade ago.

The following figure illustrates the technical point of view of the Internet of Things. Physical objects (physical things) can be represented in the information world (information world) through one or more virtual objects (virtual objects). However, virtual objects can exist independently without mapping with physical objects. A device is a device with communication capabilities and certain additional functions (sensing, driving, data retrieval, data storage and data processing). The location where the device will get the information it needs and present it as information and send it for further processing.

However, there are also some devices that can directly process it based on the information and communication received. Communication between devices: devices that can communicate via a communication network via a gateway (case A), without communicating through a gateway (case B) or directly (directly) or set up alone (case C) for communication, or between the two communications.

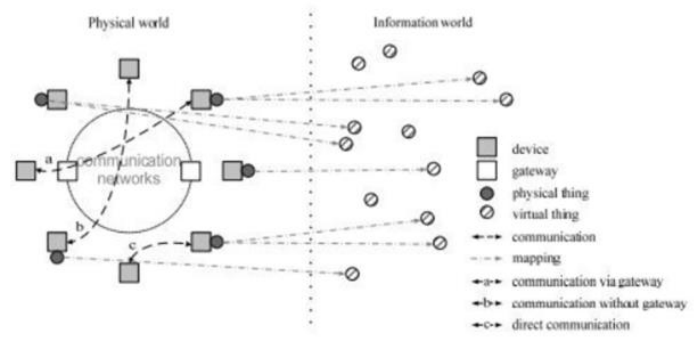

Figure 1. Communication Network

There are many benefits and conveniences when using a system in the real world. IoT devices include:

a. Data

The more information you have, the easier it will be to determine the appropriate course of action based on available data. With the help of computers and programming algorithms, 
we not only need to check the data quickly and accurately and sort them one by one, but also allow the machine to process them according to the algorithm we want.

b. Trackers

In a computer assisted inventory system it is very easy to check inventory, location and product quality, which makes it easy for us to manage, thus avoiding out of stock situations caused by negligent labor inspections.

c. Time

With the help of a programmable computer system to process certain information and take action based on the programmed content, the process of analysis and decision making based on big data will be very fast. It's impossible to imagine doing this manually without a machine.

d. Costs

It cannot be denied that the ability to use limited manpower results in a large workforce needed to complete this hard work. With the help of machines with adjustable functions that can replace humans, humans don't have to do heavy duty in today's world, they just need to be machine operators. It can be seen from this that the cost of employee salaries is reduced due to the replacement of wages with machines.

Behind the simplicity and complexity of using IoT devices you need to be aware of several risks, including several drawbacks:

a. Conformity

The sensor is not used standard, such as using USB. When a system with an IoT device breaks, you have to buy it from the same supplier to replace it.

b. Complexity

Behind this convenience is the IoT module, which is complexly assembled to receive and process information. This tool requires regular maintenance by experts to keep the system running.

c. Security

All computer devices and programs are vulnerable to hacker attacks. A large scale DDOS attack is said to have taken place. This attack is said to have originated from an IoT device that was hacked and turned into a botnet to carry out this attack. Therefore, more experts are needed to protect IoT devices from hacker attacks.

This research will use IoT Security technology which allows machines to collaborate and even act on new information obtained independently.

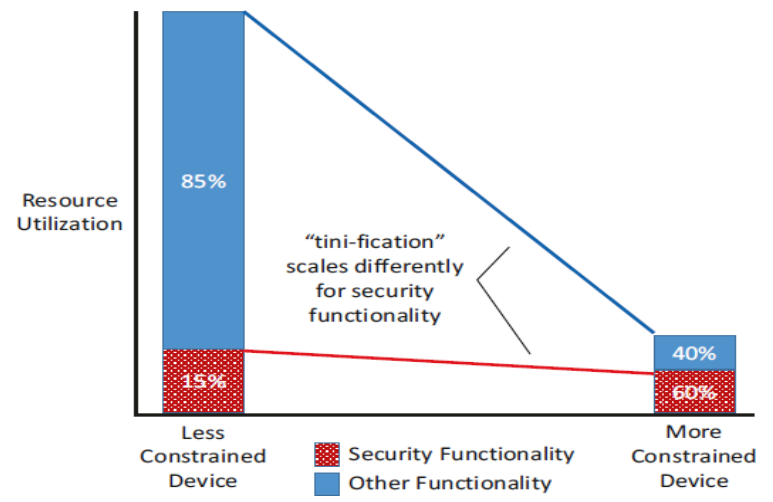

Figure 2. Overview of IoT Security

Oleg Selajev from Oracle Labs is famous on Twitter for saying, "The ' $\mathrm{S}$ ' in the IoT stands for security.

Three laws of Secure IoT:

a. Do not deploy IoT. 
b. If you use IoT, do not plug it into the power line nor internet.

c. If you power on and connect to internet, return to step 1 .

Three forms of prevalent attacks:

a. Mirai: The most damaging DoS attack in history, which spawned from insecure IoT devices in remote areas.

b. Stuxnet: A nation-state cyber weapon targeting industrial SCADA IoT devices controlling uranium enrichment centrifuges and causing substantial and irreversible damage to Iran's nuclear program.

c. Chain Reaction: A research method to exploit PAN using nothing but a lightbulb-no Internet needed.

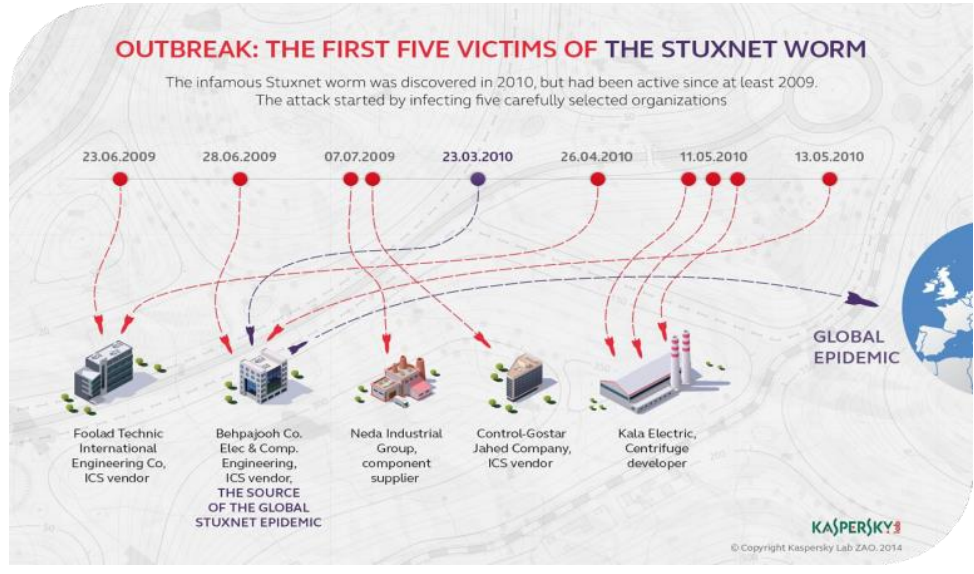

Figure 3. The First Five Victims Of The Stuxnet Worm

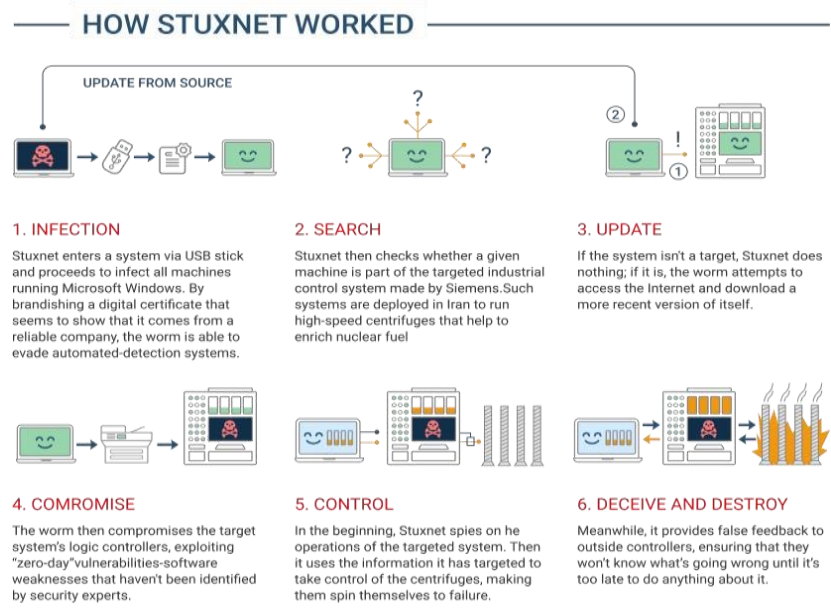

Figure 4. Examples of Outbreaks: The First Five Victims of The Stuxnet Worm

Here are some examples of IoT applications that are already used in everyday life:

a. Nest Smart Thermostat:

The Nest Smart Thermostat is one of Indonesia's Internet of Things technologies that many Indonesians like. The Nest Smart Thermostat is a smart thermostat that is connected to the internet. Nest will learn your family routine and will automatically adjust the temperature according to your home or when out, on or off, hot, or cold time, to make your home more efficient and save money. Via the mobile app, you can edit your schedule, change the temperature while you are away, and even receiving alerts when there is a problem with the heating or cooling system.

b. WeMo Switch Smart Plug: 
One of the most useful devices in the Belkin series, it is a WEMO on Switch for connecting household devices (smart plugs). It can be plugged into a regular outlet, can be connected to the power cord of any device, and can be used to turn the power on and off according to a set schedule or by pressing a button on the smartphone. Another smart plug model, the Insight switch, can also monitor the power used by devices to help you improve the energy efficiency of your home. You can view the time that the plug is used, the power used and set a schedule for normal operation of the mobile app.

c. Philips Hue Smart Bulbs:

The Philips Hue lighting system is the most popular smart lamp available today. First, Philips Hue lights can change color according to your choice; it will even match the hue of the photos you upload via the app. They can also be turned on and off according to plan or from your smartphone, and Hue lights can even sync up with your music for great party sound and light effects. Other companies have also started releasing smart tools, which give them a competitive edge. LIFX, Lumen, ilumi and Belkin all have their own versions of this technology. Like most other IoT smart home devices, it can help you save energy costs and have fun under the lights.

d. August Smart Lock:

With this smart lock, you no longer need a key to open the door when you get home. You can give the guest key to friends or whoever you want, and you can revoke the keys when you no longer want other people to visit your home. The optional keypad means you can set a code to unlock the door when you are not carrying your phone. You can even view activity logs and provide remote access from your smartphone. With more and more choices, smart security systems are becoming increasingly popular, and smart locks like this are a good starting point.

e. Canary Smart Security:

In the past, motion detectors were the most sophisticated equipment used to protect homes from intruders - but today's home monitors are much more sophisticated. For example, Canary combines video, audio, motion detection, night vision, alarm and air quality, temperature, and humidity sensors into one device that can be controlled by a mobile phone. Piper is a similar system that can act as a home security system and surveillance device and can also act as a loudspeaker so you can talk to anyone in the house even when you are away. No matter where you are, this system will limit your method of control.

The activity was held on Tuesday, June 31, 2020 from 09.00 WIB until finished, with 25 participants attended. Activities are in the form of delivering material and explaining how useful IoT Security.

Table 1. Activity

\begin{tabular}{cl}
\hline Date & \multicolumn{1}{c}{ Activities } \\
\hline 26 June 2020 & Making Activity Proposals \\
\hline 27 June 2020 & Submission of Activity Proposals to the Faculty \\
\hline 30 June 2020 & Creating Activity Materials Module \\
\hline 31 July 2020 & explaining how useful IoT Security \\
\hline 06 August 2020 & Preparation of Activity Reports \\
\hline 16 August 2020 & Activity Evaluation \\
\hline
\end{tabular}

\section{RESULT}

- Physical and hardware security: root of trust, key management and trusted platform modules, processor and memory space, storage security, physical security

- Shell security (SSH)

- Cryptography: symmetric, asymmetric, cryptography hash (authentication and signing, public key infrastructure, network stack (transport layer security) 
IoT Framework Current Trends and Recent Advances to Management Company in The PT.TNC

- Software-defined perimeter (based on the Defense Information System Agency's black cloud)

- Blockchains and cryptocurrencies in IoT

- Government regulations and intervention

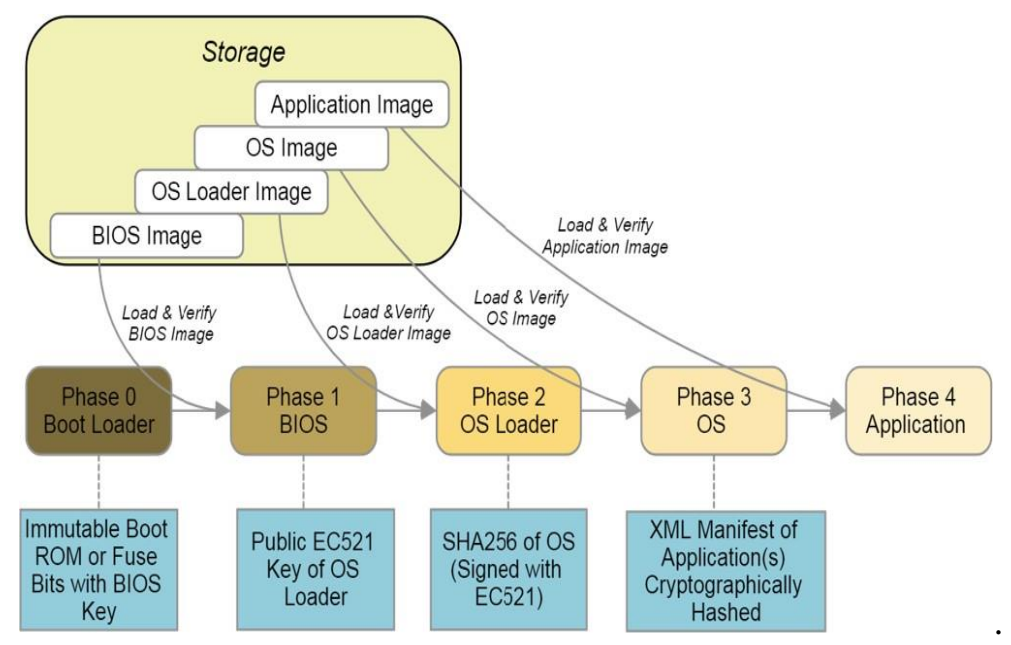

Figure 5. Physical and hardware security: Chain of Trust

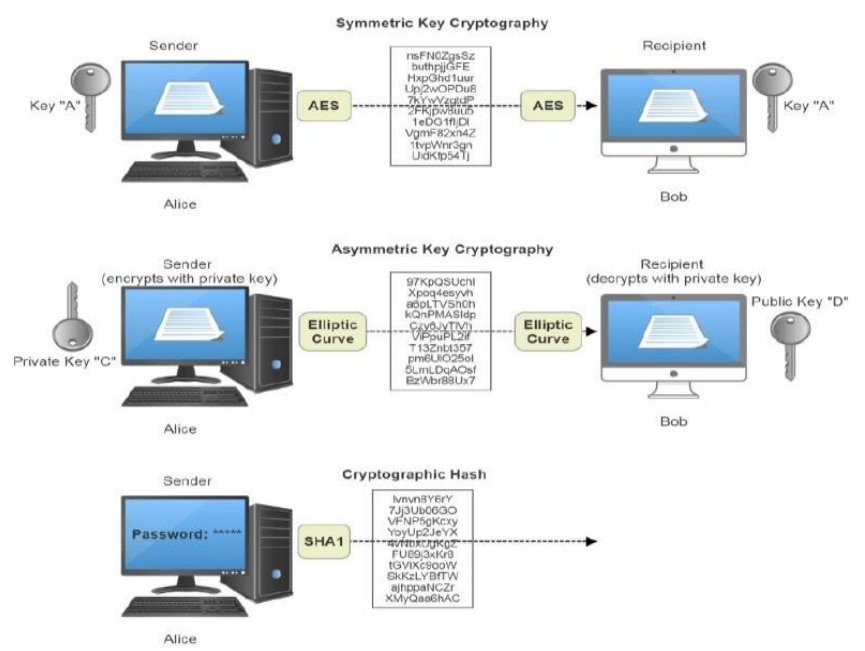

Figure 6. Symmetric Key cryptography.

Elements of cryptography. Here are symmetric, asymmetric, and hashing functions. Note the key usage in symmetric and asymmetric cryptography. Symmetric hashing has the requirement of using identical keys to encrypt and decrypt data. While faster than asymmetric encryption, the keys need to be secured.

\section{CONCLUSION}

Based on the explanation from chapter by chapter above, the writer can conclude:

a. IoT Framework: Things - Connect - Collect - Learn - Do 


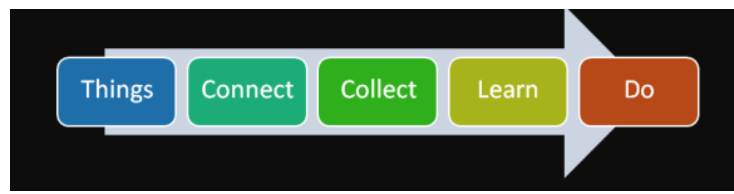

Figure 7. IoT Framework

b. The 7 properties of highly secured devices: hardware root of trust, defense in depth, small, trusted computing base, dynamic compartments, certificate-based authentication, failure reporting, renewable security.

c. Security features need to be embedded to the IoT as early as in the design process, e.g., Samsung's security chip

d. Use modern system programming language, i.e., Rust, to increase IoT security.

\section{SUGGESTION}

The results achieved from this study are far from perfect because they only use an opensource platform that is still not perfectly secure. So that to improve the results achieved, it is necessary: A personal platform that can maintain the security of the company which can only be accessed by the party in charge.

\section{THANK YOU NOTE}

Contains gratitude to service partner institutions, to those who support the implementation of service activities well and smoothly, as well as to those who provide ideas, suggestions, input and views on the preparation of this service article.

\section{REFERENCES}

[1]. Mulyono, T., Perkantoran, P. O., Komunitas, A., \& Indonesia, S. (2019). Mengembangkan Framework Implementasi Sistem Otomasi Perpustakaan Berbasis Internet of Things Developing Framework Implementation of Iot-Based Library. 2(2), 62-66.

[2]. Biasrori, R., Arimbawa, I. W. A., \& Wedashwara W., I. W. (2019). Sistem Pendukung Keputusan Konsumsi Listrik Dengan Implementasi Iot Dan Fuzzy Rule Mining. Jurnal Informatika Dan Rekayasa Elektronik, 2(1), 60. https://doi.org/10.36595/jire.v2i1.91

[3]. Kuswinta, A. J., Wedashwara W, I. G. P. W., \& Arimbawa, I. W. A. (2019). Implementasi IoT Cerdas Berbasis Inference Fuzzy Tsukamoto pada Pemantauan Kadar $\mathrm{pH}$ dan Ketinggian Air dalam Akuaponik. Journal of Computer Science and Informatics Engineering (J-Cosine), 3(1), 65-74. https://doi.org/10.29303/jcosine.v3i1.245

[4]. Sains, J. T., Gita, Y. T., Wiguna, A. S., Harianto, W., Informatika, P. T., \& Malang, U. K. (2019). Implementasi iot pada penanganan listrik padam menggunakan mikrokontroller. l(2), 1-7.

[5]. R. Hafid Hardyanto. (2017). Konsep Internet Of Things Pada Pembelajaran Berbasis Web. Jurnal Dinamika Informatika, 6(1), 87-97.

[6]. Tommy, L., S, R. P., S, M. W., Khair, R., \& Idris, I. (2020). Implementasi IOT pada Sistem Kehadiran Taruna ATKP Medan. REMIK (Riset Dan E-Jurnal Manajemen Informatika Komputer), 4(2), 89. https://doi.org/10.33395/remik.v4i2.10563

[7]. Sun, L., Li, Y., \& Memon, R. A. (2017). An Open Iot Framework Based on Microservices Architecture. China Communications, 14(2), 154-162.

[8]. Rajput, D. S., \& Gour, R. (2016). An IoT Framework for Healthcare Monitoring Systems. International Journal of Computer Science And Information Security, 14(5), 451.

[9]. Delsing, J. (Ed.). (2017). Iot Automation: Arrowhead Framework. Crc Press. 
IoT Framework Current Trends and Recent Advances to Management Company in The PT.TNC

[10]. Calderoni, L., Magnani, A., \& Maio, D. (2019). Iot Manager: An Open-Source IoT Framework for Smart Cities. Journal of Systems Architecture, 98, 413-423.

[11]. Mahmoud, R., Yousuf, T., Aloul, F., \& Zualkernan, I. (2015, December). Internet Of Things (Iot) Security: Current Status, Challenges And Prospective Measures. In 2015 10th International Conference For Internet Technology And Secured Transactions (Icitst) (Pp. 336-341). Ieee.

[12]. Rohman, F., \& Iqbal, M. (2016). Implementasi Iot Dalam Rancang Bangun Sistem Monitoring Panel Surya Berbasis Arduino. Prosiding Snatif, 189-196. 